\title{
The value of different fat supplements as sources of digestible energy for lactating dairy cows ${ }^{1}$
}

\author{
W. P. Weiss, ${ }^{2}$ J. M. Pinos-Rodríguez, ${ }^{3}$ and D. J. Wyatt \\ Department of Animal Sciences, Ohio Agricultural Research and Development Center, The Ohio State University, Wooster 44691
}

\begin{abstract}
The effects of fat supplements that differed in fatty acid composition (chain length and degree of saturation) and chemical form (free fatty acids, Ca salts of fatty acids, and triacylglyceride) on digestible energy (DE) concentration of the diet and DE intake by lactating cows were measured. Holstein cows were fed a control diet $[2.9 \%$ of dry matter $(\mathrm{DM})$ as long-chain fatty acids] or 1 of 3 diets with $3 \%$ added fatty acids (that mainly replaced starch). The 3 fat supplements were (1) mostly saturated (C18:0) free fatty acids (SFA), (2) Ca-salts of fatty acids (CaFA), and (3) triacylglyceride high in C16:0 fatty acids (TAG). Cows fed CaFA (22.8 $\mathrm{kg} / \mathrm{d}$ ) consumed less DM than cows fed the control $(23.6 \mathrm{~kg} / \mathrm{d})$ and TAG $(23.8 \mathrm{~kg} / \mathrm{d})$ diets but similar to cows fed SFA $(23.2 \mathrm{~kg} / \mathrm{d})$. Cows fed fat produced more fat-corrected milk than cows fed the control diet $(38.2$ vs. $41.1 \mathrm{~kg} / \mathrm{d})$, mostly because of increased milk fat percentage. No differences in yields of milk or milk components were observed among the fat-supplemented diets. Digestibility of DM, energy, carbohydrate fractions, and protein did not differ between diets. Digestibility of long-chain fatty acids was greatest for the CaFA diet (76.3\%), intermediate for the control and SFA diets (70.3\%), and least for the TAG diet (63.3\%). Fat-supplemented diets had more DE (2.93 Mcal/kg) than the control diet $(2.83 \mathrm{Mcal} / \mathrm{kg})$, and DE intake by cows fed supplemented diets was $1.6 \mathrm{Mcal} / \mathrm{d}$ greater than by cows fed the control, but no differences were observed among the supplements. Because the inclusion rate of supplemental fats is typically low, large differences in fatty acid digestibility may not translate into altered DE intake because of small differences in DM intake or digestibility of other nutrients.
\end{abstract}

Received August 20, 2010.

Accepted November 5, 2010.

${ }^{1}$ Partial salary and research support was provided by state and federal funds appropriated to the Ohio Agricultural Research and Development Center, The Ohio State University, Manuscript 1810AS.

${ }^{2}$ Corresponding author: weiss.6@osu.edu

${ }^{3}$ Current address: Instituto de Investigación de Zonas Deserticas, Universidad Autónoma de San Luis Potosí, Altair No. 200, Fracc. del Llano, 78377 San Luis Potosí, SLP, Mexico.
Key words: fat supplement, digestibility, energy, milk fatty acids

\section{INTRODUCTION}

In most situations, fat supplements are simply considered energy sources, hence their economic value derives largely from their ability to increase $\mathrm{NE}_{\mathrm{L}}$ intake by cows. Factors that account for essentially all the differences among fat supplements as energy sources are gross energy concentration of the supplement, digestibility of the supplement, effects of the supplement on digestibility of other dietary components, and effects on DMI. Fat supplements differ markedly in their effects on DMI: generally unsaturated fatty acids supplements tend to reduce DMI, whereas saturated fatty acids have little effect on DMI (reviewed by Allen, 2000). When saturated fat supplements were directly compared with less-saturated supplements using lactating cows, DMI was generally higher for the saturated fat treatments (Weiss and Wyatt, 2004; Harvatine and Allen, 2006a; Relling and Reynolds, 2007). Fatty acid chain length can have a modest effect on digestibility, with digestibility of total C16 fatty acids usually being higher than that of total C18 fatty acids (Elliott et al., 1995; Goodling and Grummer, 1998; Harvatine and Allen, 2006b). Last, digestibility of fatty acids fed as triacylglycerides can be substantially less than digestibility of free fatty acids (Elliott et al., 1999; Weiss and Wyatt, 2004), but the triacylglycerides in those studies were highly saturated. Less-saturated triacylglycerides may be more digestible and may have a less negative effect on DMI than unsaturated fatty acids. Abomasal infusion of unsaturated triacylglycerides (predominantly 18:2 and 18:1) did not depress DMI as much as an abomasal infusion of a similar blend of free fatty acids (Litherland et al., 2005).

Because of the importance of fatty acid digestibility when evaluating fat supplements, we conducted this experiment to examine multiple factors that can influence digestibility. We hypothesized that fat supplements based on saturated free fatty acids would be less digestible than less-saturated fatty acids but DMI would be higher. We further hypothesized that a fat supplement 
Table 1. Energy and fatty acid composition (DM basis) of the fat supplements used in this experiment ${ }^{1}$

\begin{tabular}{lccc}
\hline Item & SFA & TAG & CaFA \\
\hline Gross energy, Mcal/kg & 9.37 & 9.31 & 7.99 \\
Total long-chain fatty acids, $\%$ & 94.4 & 94.7 & 83.9 \\
Specific fatty acids, ${ }^{2} \%$ & & & \\
of total fatty acids & & & \\
$<16$ C & 3.3 & 1.4 & 1.7 \\
16:0 & 38.2 & 72.5 & 46.6 \\
16:1 & 1.1 & 0.1 & 0.2 \\
$18: 0$ & 41.2 & 5.4 & 4.3 \\
18:1 cis-9 & 6.9 & 16.4 & 36.5 \\
18:1 (others) & 3.6 & 0.0 & 0.1 \\
18:2 & 0.7 & 3.0 & 8.7 \\
$>18$ C & 0.5 & 0 & 0 \\
Unidentified & 4.5 & 1.2 & 1.9 \\
\hline
\end{tabular}

${ }^{1}$ Supplemental fat sources were saturated fatty acids (SFA, Energy Booster 100, Milk Specialties Global, Carpentersville, IL), triacylglyceride (TAG, Performance Pak 100, Milk Specialties Global), and Ca salts of fatty acids (CaFA, Megalac, Church and Dwight Co. Inc., Princeton, NJ).

${ }^{2}$ Number of carbons:number of double bonds.

based on triacylglycerides with low proportion of C18:0 (and high proportion of $\mathrm{C} 16$ and $\mathrm{C} 18: 1$ ) would have moderate digestibility and would not adversely affect DMI. The objective of this experiment was to measure nutrient digestibility, digestible energy (DE) intake, and milk production when dairy cows were fed diets that included fat supplements differing in saturation, chain length, and chemical form.

\section{MATERIALS AND METHODS}

\section{Cows and Diets}

Eight multiparous Holstein cows (average DIM was 126 at the start of the experiment) were randomly as- signed to a diet sequence in 2 replicated (orthogonal) $4 \times 4$ Latin squares. The 4 periods each lasted $21 \mathrm{~d}$, and the 4 treatment diets were control diet (no supplemental fat sources) or 1 of 3 diets with supplemental fat sources (Table 1): saturated free fatty acids (SFA, Energy Booster 100, Milk Specialties Global, Carpentersville, IL), triacylglyceride (TAG, Performance Pak 100, Milk Specialties Global), and Ca salts of fatty acids (CaFA, Megalac, Church and Dwight Co. Inc., Princeton, NJ). The diets were formulated to contain $3 \%$ added long-chain fatty acids (LCFA) and the added fat mostly replaced corn grain (Table 2). All diets were formulated to be similar in CP and NDF but, because fatty acids replaced starch, the control diet had higher concentrations of starch than did the fat-supplemented diets (Tables 2 and 3). Cows were fed once daily (approximately $5 \%$ feed refusals each day) in tie stalls and milked twice daily; daily feed intake and milk production were measured. After receiving the treatment diet for $15 \mathrm{~d}, 6$ cows (i.e., 1 full Latin square and half of the other square) were moved from conventional tie stalls to stalls designed for total collection of urine and feces (the same 6 cows were used for the entire experiment). While in the digestion stalls, cows received the same diet but daily excretion of urine and feces were measured for $4 \mathrm{~d}$ (Weiss and Wyatt, 2000) and then cows were moved back to their tie stalls and continued on the same diet. After $21 \mathrm{~d}$, cows were changed to a different diet and the process was repeated for each period. Cows were weighed on d 2 and d 21 of each period.

\section{Sampling and Analyses}

Silages were sampled each week and assayed for DM $\left(100^{\circ} \mathrm{C}\right.$ oven overnight) to adjust the as-fed TMR recipe.

Table 2. Ingredient composition of experimental diets $(\% \text { of DM })^{1}$

\begin{tabular}{|c|c|c|c|c|}
\hline Ingredient & Control & SFA & TAG & $\mathrm{CaFA}$ \\
\hline Corn silage & 40.0 & 40.0 & 40.0 & 40.0 \\
\hline Alfalfa silage & 15.0 & 15.0 & 15.0 & 15.0 \\
\hline Saturated fatty acids & - & 3.00 & - & - \\
\hline Triacylglyceride & - & - & 3.00 & - \\
\hline Ca salts of fatty acids & - & - & - & 3.60 \\
\hline Corn, ground & 23.78 & 20.10 & 20.10 & 20.42 \\
\hline Soybean meal, $44 \%$ CP & 13.00 & 13.73 & 13.73 & 13.55 \\
\hline Soyhulls & 5.90 & 5.85 & 5.85 & 6.30 \\
\hline Limestone & 1.15 & 1.15 & 1.15 & - \\
\hline Dicalcium phosphate & 0.06 & 0.06 & 0.06 & - \\
\hline Magnesium oxide & 0.03 & 0.03 & 0.03 & 0.05 \\
\hline Trace mineral salt & 0.54 & 0.54 & 0.54 & 0.54 \\
\hline Trace nutrient premix ${ }^{2}$ & 0.54 & 0.54 & 0.54 & 0.54 \\
\hline
\end{tabular}

${ }^{1}$ Diets contained supplemental fat provided by saturated free fatty acids (SFA), triacylglycerides (TAG), or Ca salts of fatty acids (CaFA).

${ }^{2}$ The premix contained $44 \mathrm{mg}$ of Se (from sodium selenate), $540 \mathrm{mg}$ of $\mathrm{Cu}$ (from copper sulfate), $720 \mathrm{mg}$ of $\mathrm{Zn}$ (from zinc sulfate), $580 \mathrm{kIU}$ of vitamin A, $162 \mathrm{kIU}$ of vitamin D, 4,000 IU of vitamin E, and $146 \mathrm{mg}$ of biotin per kilogram. 
Table 3. Assayed nutrient composition of diets (DM basis) ${ }^{1}$

\begin{tabular}{|c|c|c|c|c|}
\hline Item & Control & SFA & TAG & $\mathrm{CaFA}$ \\
\hline OM, \% & 93.7 & 93.8 & 93.8 & 93.8 \\
\hline $\mathrm{CP}, \%$ & 15.9 & 15.5 & 15.9 & 15.6 \\
\hline NDF, $\%$ & 32.2 & 32.5 & 32.4 & 32.5 \\
\hline Starch, \% & 33.4 & 29.3 & 29.1 & 28.8 \\
\hline Gross energy, Mcal/kg & 4.35 & 4.54 & 4.53 & 4.57 \\
\hline $\mathrm{NE}_{\mathrm{L}},{ }^{2} \mathrm{Mcal} / \mathrm{kg}$ & 1.55 & 1.63 & 1.61 & 1.65 \\
\hline Total long-chain fatty acids, $\%$ & 2.94 & 6.57 & 5.90 & 6.23 \\
\hline \multicolumn{5}{|l|}{ Individual fatty acids, ${ }^{3} \%$} \\
\hline$<16 \mathrm{C}$ & 0.05 & 0.20 & 0.09 & 0.10 \\
\hline C16:0 & 0.44 & 1.91 & 2.66 & 2.09 \\
\hline C16:1 & 0.03 & 0.03 & 0.02 & 0.03 \\
\hline C18:0 & 0.09 & 1.47 & 0.25 & 0.25 \\
\hline $\mathrm{C} 18: 1$ cis-9 & 0.50 & 0.69 & 0.93 & 1.64 \\
\hline C18:1 (others) & 0.04 & 0.16 & 0.05 & 0.06 \\
\hline $\mathrm{C} 18: 2$ & 1.03 & 1.12 & 1.13 & 1.19 \\
\hline C18:3 & 0.19 & 0.24 & 0.22 & 0.19 \\
\hline$>18 \mathrm{C}$ & 0.10 & 0.12 & 0.12 & 0.14 \\
\hline Unidentified & 0.46 & 0.67 & 0.44 & 0.54 \\
\hline
\end{tabular}

Milk samples (a.m. and p.m.) were taken once weekly and analyzed for milk fat, protein, lactose (B2000 Infrared Analyzer, Bentley Instruments, Chaska, MN), and MUN (Skalar SAN Plus segmented flow analyzer, Skalar Inc., Norcross, GA) by DHI Cooperative Inc. (Columbus, OH). Additional milk samples (a.m. and p.m.) were taken during the last week of each period, composited within cow and analyzed for fatty acid composition using a 2-step procedure for methylation (Jenkins, 2000) and with separation by gas-liquid chromatography using a CP-SIL88 capillary column (100 m $\times 0.25 \mathrm{~mm} \times 0.2-\mu \mathrm{m}$ film thickness; Varian Inc., Palo Alto, CA). During the 4-d collection period, silages and concentrate mixes were sampled daily and composited (by period). Each morning samples of feces (1\% of wet weight), urine ( $1 \% \mathrm{vol} / \mathrm{wt})$, and orts ( $10 \%$ of wet weight) were taken, stored in the refrigerator, and composited within cow and period. Cows were milked in the digestion stalls and milk was sampled at each milking $(1 \% \mathrm{vol} / \mathrm{wt})$ and composited. Immediately after each digestion trial, wet feces, urine, and milk were analyzed for $\mathrm{N}$ using the Kjeldahl method (AOAC, 2000). Feed, fecal, and ort samples were lyophilized and ground through a 1-mm screen (Wiley mill, Arthur H. Thomas, Philadelphia, PA). Ground samples were analyzed for $\mathrm{DM}\left(100^{\circ} \mathrm{C}\right.$ oven for $\left.24 \mathrm{~h}\right)$, ash $(\mathrm{AOAC}, 2000)$, NDF (Ankom200 Fiber Analyzer, Ankom Technology, Fairport, NY) with sodium sulfite and amylase (Ankom \#FAA), CP (Kjeldahl $\mathrm{N} \times 6.25$ ), starch (Weiss and Wyatt, 2000), energy (oxygen bomb calorimeter, model 1281, Parr Instruments, Moline, IL), and LCFA (Weiss and Wyatt, 2003), except that C19:1 was used as the internal standard instead of C19:0.

\section{Calculations and Statistics}

Daily milk yields and DMI measured during the last $10 \mathrm{~d}$ of each period were averaged within cow and analyzed statistically. Milk composition (fat, protein, lactose, and MUN) data are the average (within cow) of the weekly samples taken during wk 2 and 3 of each period. Digestibility of $\mathrm{C} 16$ and $\mathrm{C} 18$ fatty acids was calculated by summing intake of all C16 (or C18) LCFA and subtracting fecal excretion of all C16 (or C18) LCFA and dividing by intake. Digestibility of the fatty acids provided by the supplements was estimated using the method of Grummer (1988) with one modification. Rather than using mean LCFA indigestibility when cows were fed the control diet to estimate endogenous and undigested basal LCFA, LCFA indigestibility measured when each cow was fed the control diet was used for each specific cow. The cow-specific indigestibility coefficient was multiplied by intake of basal LCFA, which was estimated from the concentration of LCFA in the control diet corrected for dilution by the fat supplement. Digestibility of supplemental LCFA was also estimated by regressing intake of supplemental LCFA on intake of digestible supplemental LCFA (i.e., a Lucas test). The mean intakes of LCFA $(0.71 \mathrm{~kg} / \mathrm{d})$ and digestible LCFA $(0.50 \mathrm{~kg} / \mathrm{d})$ when cows were fed the control diet were subtracted from the actual intakes of LCFA and digestible LCFA for each observation. The slope is the 
Table 4. Effect of different types of supplemental fat on nutrient intake and digestibility (6 observations/ treatment $)^{1}$

\begin{tabular}{lcccccc}
\hline Item & Control & SFA & TAG & CaFA & SE & $P<^{3}$ \\
\hline Intake $^{2}$ & & & & & & \\
DM, kg/d & $23.9^{\mathrm{b}}$ & $23.6^{\mathrm{a}, \mathrm{b}}$ & $24.1^{\mathrm{b}}$ & $22.9^{\mathrm{a}}$ & 0.54 & 0.05 \\
Gross energy, Mcal/d & $103.8^{\mathrm{a}}$ & $106.9^{\mathrm{a}, \mathrm{b}}$ & $109.1^{\mathrm{b}}$ & $104.4^{\mathrm{a}}$ & 2.51 & 0.08 \\
LCFA, kg/d & $0.71^{\mathrm{a}}$ & $1.52^{\mathrm{c}}$ & $1.42^{\mathrm{b}}$ & $1.41^{\mathrm{b}}$ & 0.07 & 0.01 \\
Digestible LCFA, kg/d & $0.50^{\mathrm{a}}$ & $1.05^{\mathrm{c}}$ & $0.90^{\mathrm{b}}$ & $1.08^{\mathrm{c}}$ & 0.06 & 0.01 \\
Digestibility, \% & & & & & & \\
DM & 66.6 & 65.6 & 65.2 & 65.4 & 0.86 & 0.53 \\
OM & 67.5 & 66.8 & 66.4 & 66.4 & 0.86 & 0.66 \\
Energy & 65.2 & 64.5 & 64.2 & 64.9 & 0.92 & 0.81 \\
CP & 65.2 & 65.7 & 65.3 & 63.2 & 1.23 & 0.41 \\
Starch & 87.7 & 88.4 & 86.4 & 86.4 & 1.16 & 0.19 \\
NDF & 52.9 & 51.7 & 50.7 & 54.3 & 3.54 & 0.34 \\
LCFA & $71.1^{\mathrm{b}}$ & $69.5^{\mathrm{b}}$ & $63.3^{\mathrm{a}}$ & $76.3^{\mathrm{c}}$ & 1.92 & 0.01 \\
Total 16 C & $71.3^{\mathrm{b}}$ & $72.4^{\mathrm{b}}$ & $57.9^{\mathrm{a}}$ & $79.5^{\mathrm{c}}$ & 1.89 & 0.01 \\
Total 18 C & $75.4^{\mathrm{b}}$ & $69.2^{\mathrm{a}}$ & $73.2^{\mathrm{a}, \mathrm{b}}$ & $77.8^{\mathrm{b}}$ & 2.48 & 0.05 \\
Supplemental LCFA & & $68.5^{\mathrm{b}}$ & $56.3^{\mathrm{a}}$ & $81.3^{\mathrm{c}}$ & 3.25 & 0.01 \\
DE, Mcal/kg & - & $2.93^{\mathrm{b}}$ & $2.90^{\mathrm{a}, \mathrm{b}}$ & $2.97^{\mathrm{b}}$ & 0.041 & 0.03 \\
\hline
\end{tabular}

${ }^{\mathrm{a}-\mathrm{c}}$ Means with different superscripts within a row differ. Separation only conducted if treatment effect was $P$ $<0.10$.

${ }^{1}$ Diets contained supplemental fat provided by saturated free fatty acids (SFA), triacylglycerides (TAG), or Ca salts of fatty acids (CaFA). LCFA = long-chain fatty acids; DE = digestible energy.

${ }^{2}$ Intake measured during the 4 -d total collection period.

${ }^{3}$ Probability associated with treatment effect.

${ }^{4}$ Calculated (Grummer, 1988).

estimated true digestibility of supplemental LCFA. The intercept is estimated endogenous fecal excretion of supplemental LCFA; however, endogenous excretion of supplemental LCFA is not possible and all intercepts were expected to be statistically equal to zero.

Digestibility data were analyzed using Proc MIXED (SAS Institute, 2004). The model included treatment (3 df, fixed), period (3 df, random), cow (5 df, random), and error (degrees of freedom were adjusted using the Kenward-Rogers option). If treatment was significant $(P<0.10)$, means were separated using the protected least significant difference test (i.e., the PDIFF option of Proc MIXED). Digestibility of supplemental LCFA was analyzed using the same model except that only the 3 treatments with supplemental fat were included (2 df, fixed). Production data were analyzed with the same model except that 8 cows ( $7 \mathrm{df}$, random) were used.

\section{RESULTS AND DISCUSSION}

The supplemented diets were formulated to contain $3 \%$ added LCFA (approximately 6\% total LCFA) but assayed concentrations (Table 3 ) varied from 5.9 to $6.6 \%$ of diet DM (3 to 3.6 percentage units greater than that of the unsupplemented diet). Apparent digestibility of LCFA can decrease as the concentration of supplemental LCFA in diets increases (Eastridge and Firkins, 1991; Simas et al., 1998); however, in those studies concen- trations of LCFA differed by about 3 percentage units (e.g., 2 vs. $5 \%$ or 3 vs. $6 \%$ ). The differences in dietary LCFA concentrations in this study were much smaller and were probably not enough to be a significant factor for the observed treatment differences. The primary differences between the 3 supplemented treatments were type of fat and LCFA composition. The fat in the TAG treatment was triacylglyceride and was high (compared with the other supplemented diets) in C16:0 (Table 3). The fat in the SFA was free fatty acids and high in C18:0, and the fat in the CaFA was Ca salts of fatty acids and high in C18:1.

\section{Digestibility and Energy}

Treatment effects on DMI during the collection period (Table 4) followed the same general trend as DMI measured over the full experiment (Table 5) and will be discussed with the production data. Output of feces (treatment means ranged from 45.7 to $46.9 \mathrm{~kg} / \mathrm{d}$ ), urine (ranged from 14.5 to $15.9 \mathrm{~kg} / \mathrm{d}$ ), and total manure (range from 60.1 to $62.5 \mathrm{~kg} / \mathrm{d}$ ) were not affected by treatment (data not shown).

Digestibility of DM, OM, and energy averaged about $65 \%$ and were not affected by treatment (Table 4). Supplemental LCFA comprised only about 3.0, 3.2, and $6.2 \%$ of dietary DM, OM, and energy, respectively; therefore, digestibility of DM, OM, and energy are relatively insensitive to changes in digestibility of LCFA. 
Table 5. Effects of different fat supplements on production measures ( 8 observations/treatment $)^{1}$

\begin{tabular}{lcccccc}
\hline Item & Control & SFA & TAG & CaFA & SE & $P<^{2}$ \\
\hline DMI, kg/d & $23.6^{\mathrm{ab}}$ & $23.2^{\mathrm{bc}}$ & $23.8^{\mathrm{a}}$ & $22.8^{\mathrm{c}}$ & 0.45 & 0.02 \\
DE intake, Mcal/d & $66.7^{\mathrm{a}}$ & $68.2^{\mathrm{b}}$ & $68.9^{\mathrm{b}}$ & $67.8^{\mathrm{b}}$ & 1.31 & 0.04 \\
BW, kg & $636^{\mathrm{a}}$ & $626^{\mathrm{b}}$ & $635^{\mathrm{a}}$ & $627^{\mathrm{b}}$ & 14.7 & 0.01 \\
BW change, kg/d & 0.2 & 0.0 & 0.1 & 0.1 & 0.3 & 0.73 \\
Milk, kg/d & 41.3 & 42.5 & 42.4 & 42.0 & 2.52 & 0.65 \\
$4 \%$ FCM, kg/d & $38.2^{\mathrm{a}}$ & $41.4^{\mathrm{b}}$ & $41.1^{\mathrm{b}}$ & $40.9^{\mathrm{b}}$ & 1.97 & 0.03 \\
Milk fat, \% & $3.59^{\mathrm{a}}$ & $3.94^{\mathrm{b}}$ & $3.87^{\mathrm{b}}$ & $3.89^{\mathrm{b}}$ & 0.29 & 0.02 \\
Milk fat, kg/d & $1.45^{\mathrm{a}}$ & $1.63^{\mathrm{b}}$ & $1.61^{\mathrm{b}}$ & $1.61^{\mathrm{b}}$ & 0.10 & 0.03 \\
Milk protein, \% & $2.93^{\mathrm{a}}$ & $2.92^{\mathrm{a}}$ & $2.93^{\mathrm{a}}$ & $2.83^{\mathrm{b}}$ & 0.03 & 0.01 \\
Milk protein, kg/d & 1.20 & 1.22 & 1.23 & 1.19 & 0.05 & 0.48 \\
MUN, mg/dL & $9.4^{\mathrm{ab}}$ & $9.9^{\mathrm{a}}$ & $10.1^{\mathrm{a}}$ & $8.9^{\mathrm{b}}$ & 0.62 & 0.05 \\
4\% FCM/DMI & $1.62^{\mathrm{a}}$ & $1.78^{\mathrm{b}}$ & $1.73^{\mathrm{a}} \mathrm{b}$ & $1.80^{\mathrm{b}}$ & 0.08 & 0.01 \\
Milk/DMI & $1.75^{\mathrm{a}}$ & $1.82^{\mathrm{b}}$ & $1.78^{\mathrm{a}, \mathrm{b}}$ & $1.84^{\mathrm{b}}$ & 0.10 & 0.05 \\
\hline
\end{tabular}

${ }^{\mathrm{a}-\mathrm{C}}$ Means with different superscripts within a row differ $(P<0.05)$.

${ }^{1}$ Diets contained supplemental fat provided by saturated free fatty acids (SFA), triacylglycerides (TAG), or Ca salts of fatty acids (CaFA). DE = digestible energy.

${ }^{2}$ Probability associated with treatment effect.

Indeed, at typical inclusion rates $(\leq 3 \%)$, fat supplements rarely influence the digestibility of these large aggregated fractions even when the digestibility of total LCFA differs markedly (Grummer, 1988; Andrew et al., 1991; Elliott et al., 1994; Weiss and Wyatt, 2004; Harvatine and Allen, 2006b). If the supplement has negative effects on fiber digestion (Simas et al., 1998), digestibility of the aggregated fraction can be affected, but fat supplements had no effect on NDF digestibility in this study (Table 4). Digestibility of CP and the other major carbohydrate fraction, starch, were also not affected by treatment.

The apparent digestibility of LCFA for the control diet (Table 4) was similar to values obtained from other experiments (Pantoja et al., 1996b; Weiss and Wyatt, 2004; Harvatine and Allen, 2006b) when lactating cows were fed diets without added fat $(\leq 3 \%$ dietary LCFA). Apparent digestibility of total LCFA was affected by treatment $(P<0.01)$, with TAG having the lowest digestibility, the control and SFA having intermediate digestibility, and CaFA having the highest digestibility (Table 4). Differences in LCFA digestibility among the 3 supplemented diets could be a function of chemical form (triacylglyceride, free fatty acids, Ca salts of fatty acids), differences in fatty acid profile, or interactions between chemical form and fatty acid profile. To help determine the causes, digestibility coefficients for total C16 and C18 fatty acids were calculated. The digestibility coefficients for C16 LCFA followed the same pattern as did LCFA digestibility. Basal ingredients provided approximately $20 \%$ of the C16 fatty acids for the supplemented diets; therefore, differences among those 3 treatments largely reflect $\mathrm{C} 16$ provided by the supplements. The majority $(>98 \%)$ of the $\mathrm{C} 16$ in the 3 supplemented diets was C16:0; therefore, chemical form of the supplemental fat, not fatty acid, was most likely the reason for the treatment differences.

Interpretation of $\mathrm{C} 18$ digestibility is more difficult because basal ingredients provided a substantial and variable proportion of $\mathrm{C} 18$ fatty acids. For the SFA and CaFA diets, 49 and $54 \%$ of the total C18 fatty acids were derived from basal ingredients, but for the TAG diet, $71 \%$ came from basal ingredients. Therefore, digestibility of $\mathrm{C} 18$ from the TAG diet is more a reflection of basal ingredients than of the supplement. Digestibility of $\mathrm{C} 18$ from CaFA was 8.6 percentage units greater $(P$ $<0.05)$ than for the SFA but because basal ingredients provided about half the $\mathrm{C} 18$ in both those diets, the difference in digestibility of supplemental C18 is likely greater. The reason for the difference could be chemical form (free fatty acids vs. Ca salts of fatty acids) and unsaturation. For the SFA diet, $60 \%$ of the C18 fatty acids were unsaturated but almost $93 \%$ of the $\mathrm{C} 18$ fatty acids in the CaFA diet were unsaturated. Unsaturated LCFA are usually more digestible than saturated fatty acids (Pantoja et al., 1996a; Weiss and Wyatt, 2004; Harvatine and Allen, 2006a).

The digestibility of LCFA provided by the supplements was estimated by the method of Grummer (1988) and by performing a Lucas test; the values obtained with the 2 methods were virtually identical (Table 4 and Figure 1). Calculated digestibilities of LCFA in the supplements differed substantially $(P<0.01)$ with TAG having the lowest digestibility, SFA intermediate, and CaFA the highest digestibility (Table 4 and Figure 1). The NRC (2001) calculated digestibility of LCFA of various fat supplements using the same method as used in this experiment, and the digestibility values for SFA and CaFA measured in this study (69 and 81\%, respectively) agree well with the average digestibility of 


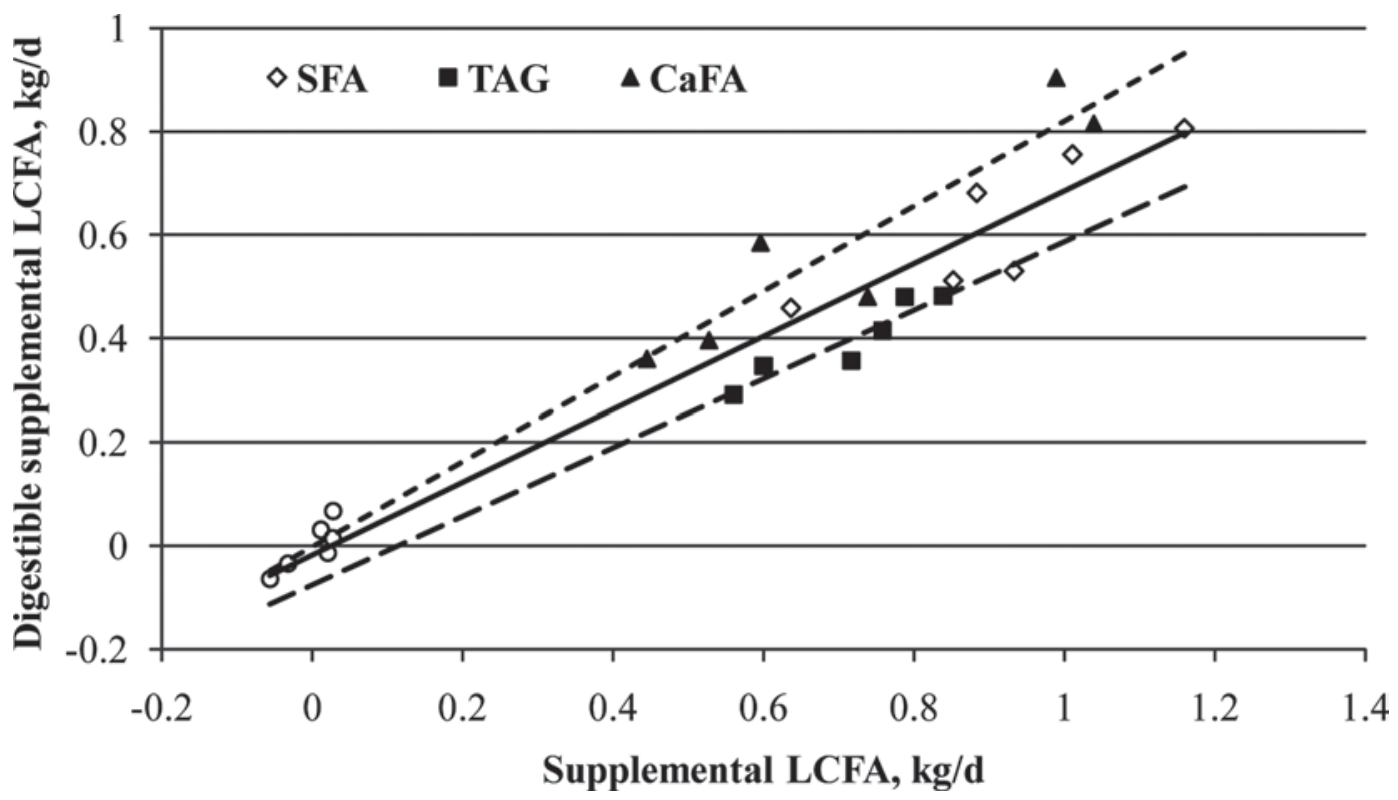

Figure 1. Lucas test to estimate the true digestibility of long-chain fatty acids (LCFA) from saturated fatty acids (SFA, solid line); triacylglycerides, (TAG, long-dashed line), and Ca salts of fatty acids (CaFA, short-dashed line). Mean intakes of LCFA and digestible LCFA when cows were fed the unsupplemented diet were subtracted from all data points. Data for the unsupplemented diet are shown $(O)$ but were not included in the regression analysis. The slopes (i.e., true digestibility of supplemental LCFA) were 0.70, 0.58, and 0.82 for SFA, TAG, and CaFA, respectively, and intercepts were not different from zero $(P>0.25)$.

LCFA from SFA (73\%) and CaFA (79\%) in NRC (2001) (after multiplying by 0.92 to convert from maintenance intake to typical DMI for lactating cows). Comparative data for the TAG diet are not available but clearly our hypothesis that TAG with a very low proportion of C18:0 would have moderate digestibility was not correct. Most studies (Pantoja et al., 1995; Elliott et al., 1999; Weiss and Wyatt, 2004), but not all (Eastridge and Firkins, 1991), reported lower LCFA digestibility when the fat supplement was a TAG rather than free fatty acids. The supplemental TAG in those studies had high proportions of C18:0 (31 to $58 \%$ of the LCFA) and the TAG in this study had only about $5 \%$ of the LCFA as C18:0 (C16:0 and C18:1 were the predominant LCFA; Table 1). Lipolysis of TAG can be a limiting step in LCFA digestion, and the rate of lipolysis varies greatly among fat sources. Generally the more unsaturated the LCFA are in the TAG, the greater the rate of lipolysis (Miller and Cramer, 1969). The TAG used in this study (approximately 19\% unsaturated LCFA) was much less saturated than the TAG used in other studies $(<10 \%)$ but the low LCFA digestibility suggests that TAG must be even more unsaturated to allow good digestibility. Esterification, rather than characteristics of the LCFA (i.e., saturation and chain length), appears to be the major factor affecting digestibility of these types of supplements.
The DE concentration of the supplements was estimated by assuming that the estimated digestibility of the supplemental fatty acids (Table 4) was equal to the digestibility of the gross energy in the supplement and multiplying that coefficient by the gross energy (Table 1) of the supplement. The resulting values were $5.4,6.4$, and $6.5 \mathrm{Mcal} / \mathrm{kg}$ for TAG, SFA, and CaFA, respectively.

Diets that contained supplemental fat had greater $(P<0.05)$ concentrations of DE than did the control diet; however, no statistical differences among the 3 fat supplement treatments were observed (Table 4), even though the digestibility of their LCFA differed markedly. Similarly, daily intake of DE by cows fed supplemented diets was about $1.6 \mathrm{Mcal} / \mathrm{d}$ greater $(P<0.05)$ than that for control cows, but no differences were observed among cows fed the different supplemented diets. Intake of LCFA was higher for cows fed SFA than for cows fed CaFA but digestibility of LCFA was higher for cows fed CaFA. The net effect was virtually identical intakes of digestible LCFA between those 2 treatments.

At higher supplementation rates (5\%), cows fed diets with SFA can have greater intakes of DE than cows fed CaFA, even though digestibility of energy is less because the higher DMI is greater than the reduction in DE concentration (Elliott et al., 1996; Harvatine and Allen, 2006b). The calculated DE concentration of the 
TAG supplement was substantially lower than that of the other 2 fat supplements, but cows fed the TAG diet had similar DE intakes because of higher DMI. Similar results were found with another TAG supplement that had low digestibility but high DMI (Weiss and Wyatt, 2004).

\section{Production Measures}

This experiment was designed primarily to measure digestibility; therefore, a short period (21 d) Latin square design was used. These experiments are statistically efficient and provide good data on digestibility, but production data (especially DMI and efficiency data) should be interpreted with caution. Fat supplementation effects on DMI may not be fully expressed for several weeks (Drackley et al., 1998), and modest daily changes in body energy stores (gain or loss) are difficult to measure with Latin square experiments because any change in DMI (and resulting increase in digesta mass) that may occur when cows change diets is measured as a change in BW.

Dry matter intake was highest for cows when fed the control and TAG diets, intermediate for cows fed SFA, and lowest for cows fed CaFA (Table 5). Cows fed CaFA had lower DMI than cows fed the control diet $(P<0.05)$, whereas DMI by cows fed the other fat supplements were similar to that of the control cows $(P$ $>0.2$ ). Intake was statistically similar for cows fed SFA and CaFA. Previous comparisons (Elliott et al., 1996; Harvatine and Allen, 2006b) between these 2 types of fat supplements found greater DMI by cows fed SFA; however, fat supplementation rates in those studies were $5 \%$ of dietary DM compared with $3 \%$ in this study.

Milk production was not affected by treatment, but feeding supplemental fat increased $(P<0.05)$ the concentration of milk fat and yields of fat and fat-corrected milk (Table 5). No differences in those measures were observed among fat supplements. Cows fed CaFA produced milk with lower protein concentrations $(P<$ $0.05)$ than that of other treatments, but protein yields were not affected by treatment. Fat supplementation increased $(P<0.05)$ intake of DE by an average of 1.6 $\mathrm{Mcal} / \mathrm{d}$ and increased fat energy excretion via milk by $1.6 \mathrm{Mcal} / \mathrm{d}$ (assuming milk fat contains $9.2 \mathrm{Mcal} / \mathrm{kg}$ ). When intake of DE by dairy cows is increased by feeding supplemental fat, milk yield, milk fat percentage (resulting in increased milk fat yield), and body energy reserves can increase. Numerous factors affect the response observed when supplemental fat is fed. Milk yield response to supplemental fat tends to be greater in early lactation than in later lactation (Onetti and Grummer, 2004). Type of forage (Onetti and Grummer, 2004), forage to concentrate ratio (Weiss and
Pinos-Rodriguez, 2009), and dietary protein (Tomlinson et al., 1994) interact with type of supplemental fat to determine which response variable is affected. The forage in the diets in this study was predominantly corn silage ( $73 \%$ of forage DM) and diets contained moderate concentrations of total forage (55\% of diet DM). When diets that are predominantly corn silage are supplemented with either CaFA or SFA, yields of milk and milk fat usually increase (Onetti and Grummer, 2004). We observed an increase in milk fat yield for all 3 fat supplements, which was caused by increased milk fat concentration.

Feeding supplemental fat often reduces milk protein percentage regardless of the type of fat supplement (Onetti and Grummer, 2004); however, in this experiment only CaFA reduced $(P<0.05)$ milk protein percentage. Treatment did not affect protein yields. The concentration of MUN was similar for all treatments except for SFA, which was higher $(P<0.05)$ than the other treatments. The mechanism by which supplemental fat often reduces milk protein percentage is not known but may involve supply of MP. Because DMI was lowest for CaFA diet, MP supply was lower than that for other diets. Calculated (NRC, 2001) supply of MP was 2,500, 2,440, 2,510, and 2,360 g/d for control, SFA, TAG, and CaFA diets, respectively (calculated based on treatment mean DMI).

\section{Milk Fatty Acids}

Changes in milk fatty acids (Table 6) largely reflected changes in dietary LCFA (Table 3). Feeding any of the 3 fat supplements reduced $(P<0.05)$ the concentration of total short-chain fatty acids $(<16 \mathrm{C}$; SCFA) in milk, with CaFA causing the greatest $(P<0.05)$ reduction. Most individual SCFA followed the same response (highest for control, intermediate for SFA and TAG, and lowest for CaFA). The decrease in the percentage of SCFA was probably mostly caused by dilution from the incorporation of dietary LCFA into the milk. A greater dilution would be expected by cows fed CaFA because of the greater intake of digestible LCFA by cows fed that supplement. Similarly, Harvatine and Allen (2006b) reported higher proportions of SCFA and lower proportions of LCFA in milk from cows fed SFA compared with those fed CaFA but they attributed that difference mostly to decreased fatty acid synthesis by cows fed CaFA. In their study, milk fat yields were lower for cows fed CaFA than for those fed SFA but that did not happen in our study. Cows fed the 3 supplements had increased $(P<0.05)$ concentrations of $C 16: 0$ with the greatest concentration occurring when TAG was fed $(P<0.05)$. The TAG supplement had much higher concentrations of $\mathrm{C} 16$ than did the other supplements 
Table 6. Effect of fat supplements on the fatty acid (FA) profile of milk (\% of total FA) ${ }^{1}$

\begin{tabular}{|c|c|c|c|c|c|c|}
\hline $\mathrm{FA}^{2}$ & Control & SFA & TAG & $\mathrm{CaFA}$ & $\mathrm{SE}$ & $P<<^{3}$ \\
\hline 4:0 & 3.97 & 4.06 & 3.96 & 4.23 & 0.22 & 0.27 \\
\hline $6: 0$ & $2.81^{\mathrm{a}}$ & $2.56^{\mathrm{b}}$ & $2.57^{\mathrm{b}}$ & $2.37^{\mathrm{c}}$ & 0.16 & 0.001 \\
\hline $8: 0$ & $1.51^{\mathrm{a}}$ & $1.24^{\mathrm{b}}$ & $1.25^{\mathrm{b}}$ & $1.08^{\mathrm{c}}$ & 0.09 & 0.001 \\
\hline 10:0 & $3.62^{\mathrm{a}}$ & $2.70^{\mathrm{b}}$ & $2.75^{\mathrm{b}}$ & $2.21^{\mathrm{c}}$ & 0.22 & 0.001 \\
\hline $12: 0$ & $4.23^{\mathrm{a}}$ & $3.04^{\mathrm{b}}$ & $3.10^{\mathrm{b}}$ & $2.45^{\mathrm{c}}$ & 0.23 & 0.001 \\
\hline 14:0 & $12.97^{\mathrm{a}}$ & $11.09^{\mathrm{b}}$ & $10.62^{\mathrm{c}}$ & $9.27^{\mathrm{d}}$ & 0.27 & 0.001 \\
\hline $14: 1$ & $1.25^{\mathrm{a}}$ & $1.15^{\mathrm{a}, \mathrm{b}}$ & $1.06^{\mathrm{b}}$ & $0.80^{\mathrm{c}}$ & 0.13 & 0.001 \\
\hline 15:0 & $1.65^{\mathrm{a}}$ & $1.38^{\mathrm{b}}$ & $1.17^{\mathrm{b}}$ & $0.85^{\mathrm{c}}$ & 0.12 & 0.001 \\
\hline SCFA & $30.77^{\mathrm{a}}$ & $26.09^{\mathrm{b}}$ & $25.42^{\mathrm{b}}$ & $22.46^{\mathrm{c}}$ & 1.00 & 0.001 \\
\hline $16: 0$ & $32.20^{\mathrm{c}}$ & $33.85^{\mathrm{b}}$ & $37.60^{\mathrm{a}}$ & $33.68^{\mathrm{b}}$ & 0.77 & 0.001 \\
\hline $16: 1$ & $2.24^{\mathrm{b}}$ & $2.44^{\mathrm{a}}$ & $2.32^{\mathrm{a}, \mathrm{b}}$ & $1.87^{\mathrm{c}}$ & 0.10 & 0.001 \\
\hline $17: 0$ & $0.80^{\mathrm{b}}$ & $0.94^{\mathrm{a}}$ & $0.59^{\mathrm{c}}$ & $0.42^{\mathrm{d}}$ & 0.06 & 0.001 \\
\hline $18: 0$ & $8.18^{\mathrm{b}}$ & $9.48^{\mathrm{a}}$ & $8.06^{\mathrm{b}}$ & $9.74^{\mathrm{a}}$ & 0.47 & 0.001 \\
\hline $18: 1$ trans $-6,8$ & $0.42^{\mathrm{b}}$ & $0.41^{\mathrm{b}}$ & $0.41^{\mathrm{b}}$ & $0.62^{\mathrm{a}}$ & 0.058 & 0.001 \\
\hline $18: 1$ trans -9 & $0.27^{\mathrm{b}}$ & $0.30^{\mathrm{b}}$ & $0.27^{\mathrm{b}}$ & $0.40^{\mathrm{a}}$ & 0.032 & 0.001 \\
\hline 18:1 trans -10 & 1.47 & 1.28 & 1.09 & 1.09 & 0.38 & 0.65 \\
\hline $18: 1$ trans -11 & $1.03^{\mathrm{b}}$ & $0.69^{c}$ & $0.98^{\mathrm{b}}$ & $1.19^{\mathrm{a}}$ & 0.09 & 0.001 \\
\hline $18: 1$ trans -12 & $0.51^{\mathrm{b}}$ & $0.51^{\mathrm{b}}$ & $0.54^{\mathrm{b}}$ & $0.77^{\mathrm{a}}$ & 0.04 & 0.001 \\
\hline $18: 1$ cis -9 & $16.23^{\mathrm{d}}$ & $19.16^{\mathrm{b}}$ & $17.74^{\mathrm{c}}$ & $22.32^{\mathrm{a}}$ & 0.78 & 0.001 \\
\hline $18: 1$ cis-11 & 0.68 & 0.66 & 0.62 & 0.62 & 0.07 & 0.67 \\
\hline $18: 2$ & $2.85^{\mathrm{a}}$ & $2.26^{\mathrm{b}}$ & $2.37^{\mathrm{b}}$ & $2.85^{\mathrm{a}}$ & 0.14 & 0.001 \\
\hline $18: 3$ & $0.54^{\mathrm{a}}$ & $0.43^{\mathrm{b}}$ & $0.43^{\mathrm{b}}$ & $0.46^{\mathrm{b}}$ & 0.02 & 0.001 \\
\hline CLA & $0.55^{\mathrm{a}}$ & $0.38^{\mathrm{b}}$ & $0.52^{\mathrm{a}}$ & $0.64^{\mathrm{a}}$ & 0.07 & 0.001 \\
\hline LCFA & $33.52^{\mathrm{c}}$ & $36.48^{\mathrm{b}}$ & $33.62^{\mathrm{c}}$ & $41.14^{\mathrm{a}}$ & 1.11 & 0.001 \\
\hline
\end{tabular}

${ }^{\mathrm{a}-\mathrm{d}}$ Means with different superscripts within a row differ $(P<0.01)$.

${ }^{1}$ Diets contained supplemental fat provided by saturated free fatty acids (SFA), triacylglycerides (TAG), or Ca salts of fatty acids (CaFA).

${ }^{2}$ Number of carbons:number of double bonds. SCFA = short-chain FA $(<16 \mathrm{C})$; LCFA = long-chain FA $(>16 \mathrm{C})$; CLA = conjugated linoleic acid (only cis-9, trans-11 isomer was detected).

${ }^{3}$ Probability associated with treatment effect.

but the relative difference between fat supplements for $\mathrm{C} 16$ in milk was much less than differences in diets because of the low digestibility of $\mathrm{C} 16$ fatty acids by cows fed the TAG supplement (Table 4). Cows fed SFA or CaFA had similar concentrations of $\mathrm{C} 16$ in milk fat, whereas Harvatine and Allen (2006b) reported lower concentrations of $\mathrm{C} 16$ by cows fed CaFA. The difference between studies is probably a result of different treatment effects on DMI and milk fat yield and concentration. Harvatine and Allen (2006a,b) reported that cows fed CaFA had lower DMI and milk fat yields than cows fed SFA.

Total LCFA in milk fat $(>16 \mathrm{C})$ was greatest for CaFA, intermediate for SFA, and lowest for TAG and control. This reflects differences in dietary LCFA and differences in digestibility. The concentration of C18:0 was higher $(P<0.05)$ for SFA and CaFA compared with control or TAG. The SFA diet had the greatest concentration of C18:0; however, C18:0 concentrations in milk fat were similar for cows fed SFA or CaFA. The CaFA diet had the greatest concentration of C18:1 and cows fed the diet had the highest concentration of C18:1 in milk fat, but the difference between treatments in dietary concentrations of C18:1 was much greater than differences in C18:1 in milk fat. The increased concentration of C18:0 and decreased relative difference in C18:1 in milk fat for cows fed CaFA indicates biohydrogenation of some of the dietary C18:1.

\section{CONCLUSIONS}

Three fat supplements that differed in fatty acid composition and chemical form also differed substantially in fatty acid digestibility (range in calculated digestibility of the supplements was 25 percentage units). Less-saturated supplements were more digestible than more-saturated supplements, and fatty acids supplements were much more digestible than TAG supplements. Supplementing diets with fat increased the concentration of DE and DE intake by cows, but the wide range in fatty acid digestibility for the supplements did not translate into differences in DE concentrations of diets or in DE intake by cows when fed the various supplements. The increased intake of DE when cows were fed fat supplements was largely partitioned into increased milk yields. 


\section{ACKNOWLEDGMENTS}

The authors gratefully acknowledge Milk Specialties Global (Carpentersville, IL) for partial support of this project. Al Kertz, of Milk Specialties Global, provided helpful suggestions regarding experimental design and results.

\section{REFERENCES}

Allen, M. S. 2000. Effects of diet on short-term regulation of feed intake by lactating dairy cows. J. Dairy Sci. 83:1598-1624.

Andrew, S. M., H. F. Tyrrell, C. K. Reynolds, and R. A. Erdman. 1991. Net energy for lactation of calcium salts of long-chain fatty acids for cows fed silage-based diets. J. Dairy Sci. 74:2588-2600.

Association of Official Analytical Chemists. 2000. Official Methods of Analysis. Vol. 1 and 2. 17th ed. AOAC Int., Gaithersburg, MD.

Drackley, J. K., D. W. LaCount, J. P. Elliott, T. H. Klusmeyer, T. R. Overton, J. H. Clark, and S. A. Blum. 1998. Supplemental fat and nicotinic acid for Holstein cows during an entire lactation. J. Dairy Sci. 81:201-214.

Eastridge, M. L., and J. L. Firkins. 1991. Feeding hydrogenated fatty acids and triglycerides to lactating dairy cows. J. Dairy Sci. 74:2610-2616.

Elliott, J. P., J. K. Drackley, A. D. Beaulieu, C. G. Aldrich, and N. R. Merchen. 1999. Effects of saturation and esterification of fat sources on site and extent of digestion in steers: Digestion of fatty acids, triglycerides, and energy. J. Anim. Sci. 77:1919-1929.

Elliott, J. P., J. K. Drackley, J. G. C. Fahey, and R. D. Shanks. 1995. Utilization of supplemental fat by dairy cows fed diets varying in content of nonstructural carbohydrates. J. Dairy Sci. 78:15121525 .

Elliott, J. P., J. K. Drackley, and D. J. Weigel. 1996. Digestibility and effects of hydrogenated palm fatty acid distillate in lactating dairy cows. J. Dairy Sci. 79:1031-1039.

Elliott, J. P., T. R. Overton, and J. K. Drackley. 1994. Digestibility and effects of three forms of mostly saturated fatty acids. J. Dairy Sci. $77: 789-798$.

Goodling, L. E., and R. R. Grummer. 1998. Effects of postruminal protein on fatty acid digestibility in dairy cows. J. Dairy Sci. 81:1624-1629.

Grummer, R. R. 1988. Influence of prilled fat and calcium salts of palm oil fatty acids on ruminant fermentation and nutrient digestibility. J. Dairy Sci. 71:117-123.

Harvatine, K. J., and M. S. Allen. 2006a. Effects of fatty acid supplements on feed intake, and feeding and chewing behavior of lactating dairy cows. J. Dairy Sci. 89:1104-1112.

Harvatine, K. J., and M. S. Allen. 2006b. Effects of fatty acid supplements on ruminal and total tract nutrient digestion in lactating dairy cows. J. Dairy Sci. 89:1092-1103.
Jenkins, T. C. 2000. Feeding oleamide to lactating Jersey cows 1. Effects on lactation performance and milk fatty acid composition. J. Dairy Sci. 83:332-337.

Litherland, N. B., S. Thire, A. D. Beaulieu, C. K. Reynolds, J. A. Benson, and J. K. Drackley. 2005. Dry matter intake is decreased more by abomasal infusion of unsaturated free fatty acids than by unsaturated triglycerides. J. Dairy Sci. 88:632-643.

Miller, L. G., and D. A. Cramer. 1969. Metabolism of naturally occurring and ${ }^{14} \mathrm{C}$-labeled triglycerides in the sheep. J. Anim. Sci. 29:738-745.

National Research Council. 2001. Nutrient Requirements of Dairy Cattle. 7th rev. ed. Natl. Acad. Press, Washington, DC.

Onetti, S. G., and R. R. Grummer. 2004. Response of lactating cows to three supplemental fat sources as affected by forage in the diet and, stage of lactation: A meta-analysis of literature. Anim. Feed Sci. Technol. 115:65-82.

Pantoja, J., J. L. Firkins, and M. L. Eastridge. 1995. Site of digestion and milk production by cows fed fats differing in saturation, esterification and chain length. J. Dairy Sci. 78:2247-2258.

Pantoja, J., J. L. Firkins, and M. L. Eastridge. 1996a. Fatty acid digestibility and lactation performance by dairy cows fed fats varying in degree of saturation. J. Dairy Sci. 79:429-437.

Pantoja, J., J. L. Firkins, M. L. Eastridge, and B. L. Hull. 1996b. Fatty acid digestion in lactating dairy cows fed fats varying in degree of saturation and different fiber sources. J. Dairy Sci. 79:575-584.

Relling, A. E., and C. K. Reynolds. 2007. Feeding rumen-inert fats differing in their degree of saturation decreases intake and increases plasma concentrations of gut peptides in lactating dairy cows. J. Dairy Sci. 90:1506-1515.

SAS Institute. 2004. SAS/STAT ${ }^{\circledR}$ User's Guide. Version 9. SAS Institute Inc., Cary, NC.

Simas, J. M., J. T. Huber, C. B. Theurer, K. H. Chen, F. A. P. Santos, and Z. Wu. 1998. Influence of sorghum grain processing on performance and nutrient digestibilities in dairy cows fed varying concentrations of fat. J. Dairy Sci. 81:1966-1971.

Tomlinson, A. P., H. H. Van Horn, C. J. Wilcox, and B. Harris Jr.. 1994. Effects of undegradable protein and supplemental fat on milk yield and composition and physiological responses of cows. J. Dairy Sci. 77:145-156.

Weiss, W. P., and J. M. Pinos-Rodriguez. 2009. Production responses by dairy cows when fed supplemental fat in low and high forage diets. J. Dairy Sci. 92:6144-6155.

Weiss, W. P., and D. J. Wyatt. 2000. Effect of oil content and kernel processing of corn silage on digestibility and milk production by dairy cows. J. Dairy Sci. 83:351-358.

Weiss, W. P., and D. J. Wyatt. 2003. Effect of dietary fat and vitamin $\mathrm{E}$ on $\alpha$-tocopherol in milk from dairy cows. J. Dairy Sci. 86:3582-3591.

Weiss, W. P., and D. J. Wyatt. 2004. Digestible energy values of diets with different fat supplements when fed to lactating dairy cows. J. Dairy Sci. 87:1446-1454. 